\title{
REACTION OF POTATO CULTIVARS AND CLONES TO Phytophthora infestans ${ }^{1}$
}

\author{
VICTOR HUGO CASA-COILA ${ }^{2}$, CESAR BAUER GOMES ${ }^{3 *}$, ISRAEL LIMA-MEDINA ${ }^{4}$, DEDIEL JUNIOR AMARAL \\ ROCHA $^{5}$, ARIONE DA SILVA PEREIRA ${ }^{3}$, AILTON REIS ${ }^{6}$
}

\begin{abstract}
The in vitro and field reactions of 23 potato cultivars and clones to two isolates of Phytophthora infestans were tested. The in vitro test used the detached potato leaflets method, and disease severity was evaluated 6 days after inoculation. Field experiments were conducted in autumn of 2013, in two locations in Pelotas City, Rio Grande do Sul State, Brazil. Seven evaluations of the disease severity were performed. From the severity values, the area under the disease progress curve (AUDPC) was calculated. Tubers were harvested to determine the yield $\left(\mathrm{g} \mathrm{plot}^{-1}\right)$. The A2 mating type isolate was the most aggressive for the majority of the potato genotypes. It was possible to group the different reactions of the potato genotypes based on the AUDPC values. Clones C2553-1-06, C2573-4-06, C2550-4-06, C2551-2-06, and CIP392,617.54 showed moderate-tohigh resistance to the two isolates of $P$. infestans. The values of severity and AUDPC obtained in vitro and field tests were positively correlated for both $P$. infestans isolates, but in some interactions, inconsistencies were observed. Tuber yield was negatively correlated with AUDPC.
\end{abstract}

Keywords: Solanum tuberosum. Late blight. Pathotypes. Disease resistance.

\section{REAÇÃO DE CULTIVARES E CLONES DE BATATA A Phytophthora infestans}

RESUMO - A reação in vitro e a campo de 23 cultivares e clones de batata a dois isolados de Phytophthora infestans foram avaliadas utilizando-se dois métodos. No teste in vitro, utilizou-se o método de folíolos destacadas cuja severidade da doença foi avaliada 6 dias após a inoculação. Os experimentos de campo foram conduzidos no outono de 2013, em dois locais distintos do Município de Pelotas, Estado do Rio Grande do Sul, Brasil. Foram realizadas sete avaliações da severidade da doença; e, a partir desses valores, foi calculada a área abaixo da curva de progresso da doença (AACPD). Os tubérculos foram colhidos para determinar o rendimento $\left(\mathrm{g}_{\text {parcela }}{ }^{-1}\right)$. O isolado do grupo de compatibilidade A2 foi o mais agressivo para a maioria dos genótipos de batata. Com base nos valores de AACPD foi possível agrupar as diferentes reações dos genótipos de batata. Os clones C2553-1-06, C2573-4-06, C2550-4-06, C2551-2-06 e CIP392,617.54 apresentaram resistência moderada a alta aos dos isolados de $P$. infestans. Os valores de severidade e AACPD obtidos in vitro e nos testes a campo foram correlacionados positivamente para ambos os isolados de $P$. infestans, porém, em algumas interações, foram observadas inconsistências. A produção de tubérculos foi negativamente correlacionada com a AACPD.

Palavras-chave: Solanum tuberosum. Requeima. Patótipos. Resistencia a doenças.

\footnotetext{
"Corresponding author

${ }^{1}$ Received for publication in $07 / 16 / 2018$; accepted in 02/04/2019.

Paper extracted from the doctoral thesis of the first author.

${ }^{2}$ Universidad Nacional de San Agustín de Arequipa, Arequipa, Peru; vcasac@unsa.edu.pe - ORCID: 0000-0001-5081-6401.

${ }^{3}$ Embrapa Clima Temperado, Pelotas, RS, Brazil; cesar.gomes@embrapa.br - ORCID: 0000-0002-3247-728X, arione.pereira@embrapa.br - ORCID: 0000-0001-9295-6496.

${ }^{4}$ Faculty of Agricultural Sciences, Universidad Nacional del Altiplano, Puno, Peru; islimes@hotmail.com - ORCID: 0000-0003-46418640 .

${ }^{5}$ Empresa de Pesquisa Agropecuária e Extensão Rural de Santa Catarina, Lages, SC, Brazil; dedielrocha@hotmail.com - ORCID: 00000002-0438-0560.

${ }^{6}$ Embrapa Hortaliças, Brasília, DF, Brazil; ailton.reis@embrapa.br - ORCID: 0000-0002-5705-3002.
} 


\section{INTRODUCTION}

Potato (Solanum tuberosum L.) is the fourth most important crop in the world. In Brazil, the production is $3,851,396$ ton from 129,842 ha of harvested area (FAO, 2018). Among the factors that affect the yield of this crop, the diseases stand out because they cause serious damages. The oomycete Phytophthora infestans (Mont.) De Bary, the causal agent of late blight, is a highly destructive pathogen (GISI et al., 2011). This pathogen can limit tuber yield in different regions of Brazil. Regions presenting high relative humidity, temperatures between 12 and $20{ }^{\circ} \mathrm{C}$, frequent rainfall, and susceptible potato cultivars are favorable to the occurrence of late blight epidemics, causing losses in a few days if adequate control measures are not adopted (ZAMBOLIM; DUARTE; ZAMBOLIM, 2011).

The variability and plasticity of the genome of this oomycete are enormous challenges in the adoption of effective control measures against potato late blight (FRY, 2008). Changes in P. infestans populations in a given region are mainly due to migrations (FRY et al., 1993). Consequently, changes in aggressiveness in these populations have been detected in different regions of the world, such as those observed by Cooke et al. (2012) in Great Britain, where in the emergence of the highly aggressive 13-A2 genotype, displaced the old pathogen population.

Progressive changes in the composition of the $P$. infestans population in Brazil have been confirmed by the presence of the A1 and A2 mating types and mitochondrial Ia and IIa haplotypes of potatoes. These genotypes are typical of new and highly aggressive strains. There is also the US-1 population, but it is only aggressive toward tomatoes (REIS et al., 2003; SANTANA et al., 2013). Recently, new genotypes of $P$. infestans, including self-fertile isolates, has been detected in potato crops in southern Brazil (CASA-COILA et al., 2017).

The regular application of fungicides is the most common management measure used in the control of potato late blight (NAZARENO et al., 1999). However, despite the use of these products, potato crops with high severity of the disease have been observed (ORONA et al., 2013). The reduced efficiency of these fungicides in the control of late blight (i.e., the loss of sensitivity of $P$. infestans toward fungicides) is due to the inadequate use of the chemical products over time, mainly the systemic compounds (GISI et al., 2011).

Although the use of resistant potato cultivars is one of the most desirable management strategies for late blight control in potatoes, the majority of cultivars available for the Brazilian growers are susceptible or moderately susceptible to the pathogen (GOMES et al., 2009; DUARTE et al., 2012) or show pathotype-specific resistance, which is inefficient over time (FRY, 2008). This type of resistance differs from non-specific pathotype resistance, which is characterized by greater resistance stability against a greater number of $P$. infestans pathotypes (VAN DER PLANK, 1971).

Nowadays, breeding programs tend to select potato genotypes having a quantitative type of resistance to $P$. infestans (LANDEO et al., 2001; PEREIRA et al., 2012), which is why genotypes of the B3 population, developed by the International Potato Center (CIP), have been widely used in breeding programs (BYARUGABA; PROSSY; KASHAIJA, 2013; NDACYAYISENGA et al., 2014). This population is free of known major resistance $(R)$ genes (LANDEO et al., 2001; NAKITANDWE et al., 2005). According to Namugga et al. (2018), advanced clones from the B3 population of CIP, with horizontal resistance to $P$. infestans, demonstrate great potential for breeding programs that include resistance to late blight.

Despite the existence of promising genotypes, few studies of selection or pre-selection of resistant potato accesses, using the most aggressive isolates of distinct mating type and races of $P$. infestans, have been conducted in Brazil and worldwide. Therefore, this work sought to evaluate the resistance of 23 potato genotypes from the Embrapa breeding program to two distinct $P$. infestans isolates belonging to the A1 and A2 mating types.

\section{MATERIAL AND METHODS}

Twenty-three potato genotypes were evaluated, including eight cultivars (Macaca, Asterix, Clara, Ana, Eliza, Bel, Ágata, and Bintje), six clones from the Embrapa breeding program developed for tuber quality (RM9823-05, CL02-05, F23-24-06, F63-01-06, F189-09-06, and CL20-01$06)$, and eight clones selected for resistance to $P$. infestans from the Embrapa breeding program (C2572-3-06, C2557-2-06, C2569-1-06, C2553-106, C2573-4-06, C2550-4 -06, C2551-2-06, and C2545-1-06) and one from the CIP breeding program (CIP392.617-54, resistant control), belonging to the B3 population. The resistant clones from the Embrapa breeding program were derived from crosses with clones of B3 population.

Two isolates were used. The A1 mating type isolate, containing two virulence genes, simple race (3.6); and, the A2 mating type isolate, containing 10 virulence genes, complex race (1. 2. 3. 4. 5. 6. 7. 8 . 9. 11). The mating type of both isolates was previously determined by pairing them with standard isolates of $P$. infestans A1 (US-1) and A2 (BR-1) (SANTANA et al., 2013). Race identification was carried out by inoculating the isolates in a series of R1-R11 differential clones (BLACK et al., 1953).

The detached leaflet method was used to evaluate the potato genotypes for the in vitro 
resistance of two $P$. infestans isolates. Tubers of the 23 potato genotypes were first planted in $2-\mathrm{L}$ plastic pots containing commercial substrate fertilized with NPK (5-30-10), in the greenhouse. Forty days after planting, leaves of each potato genotype were removed to take leaflets that were evaluated according to the procedure described by Colon, Nielson and Darson, (2004). Five leaflets per genotype for each isolate were washed carefully and arranged by placing the abaxial face on Germtest ${ }^{\circledR}$ paper moistened with sterilized water, in a plastic tray $(46 \times 30 \times 10 \mathrm{~cm})$. A completely randomized design with five replications in a factorial scheme of $23 \times 2$ was used. The leaflets were inoculated with an aqueous suspension containing $20 \mu \mathrm{L}$ of $5 \times 10^{5}$ sporangia $\mathrm{mL}^{-1}$ from one isolate of either the mating type A1 or A2. The trays containing the inoculated plant material were sealed with transparent plastic film, and maintained in a BOD incubator at $17 \pm 1{ }^{\circ} \mathrm{C}$, with a photoperiod of $16 \mathrm{~h}$ light and $8 \mathrm{~h}$ darkness, for 6 days. The disease severity was evaluated as the percentage of leaflet area affected $(0.1-100 \%)$, according to Colon, Nielson and Darson, (2004).

Field experiments were conducted in two different experimental areas of Embrapa Temperate
Agriculture, in Pelotas City of Rio Grande do Sul State, Brazil (A1 isolate: $31^{\circ} 40^{\prime} 30^{\prime \prime} \mathrm{S}, 52^{\circ} 26^{\prime} 06^{\prime \prime} \mathrm{W}$; A2 isolate: $31^{\circ} 41^{\prime} 10^{\prime \prime S}, 52^{\circ} 26^{\prime} 11^{\prime \prime} \mathrm{W}$ ) during the autumn season of 2013. A randomized complete block design with three replications in a factorial scheme of $23 \times 2$ was used. Each plot consisted of a row of 8 plants inter-spaced by $0.30 \mathrm{~m}$ and with an inter-row spacing of $0.80 \mathrm{~m}$, fertilized with NPK 530-10 (2.0 $\left.\mathrm{t} \mathrm{ha}^{-1}\right)$. Forty-seven days after planting (start of tuberization), the potato plants of each experiment were artificially inoculated with a liquid suspension of $5 \times 10^{4} \mathrm{P}$. infestans sporangia $\mathrm{mL}^{-1}$ from each isolate, separately. In one experiment, the plants were inoculated with the A1 isolate and, in the other, with the A2 isolate.

The severity of disease (SEV) was evaluated seven times from the 7th day after inoculation (DAI), not at constant intervals, until the 28th DAI, using a diagrammatic scale of disease severity proposed by Clive (1971). From the inoculation period of the plants until the last evaluation of the SEV, the average temperature was $13.8{ }^{\circ} \mathrm{C}$ (range, $4-24{ }^{\circ} \mathrm{C}$ ), the accumulated rainfall was $57.1 \mathrm{~mm}$, and the mean relative humidity was $72 \%$ (range, 45-88\%) (Figure 1).

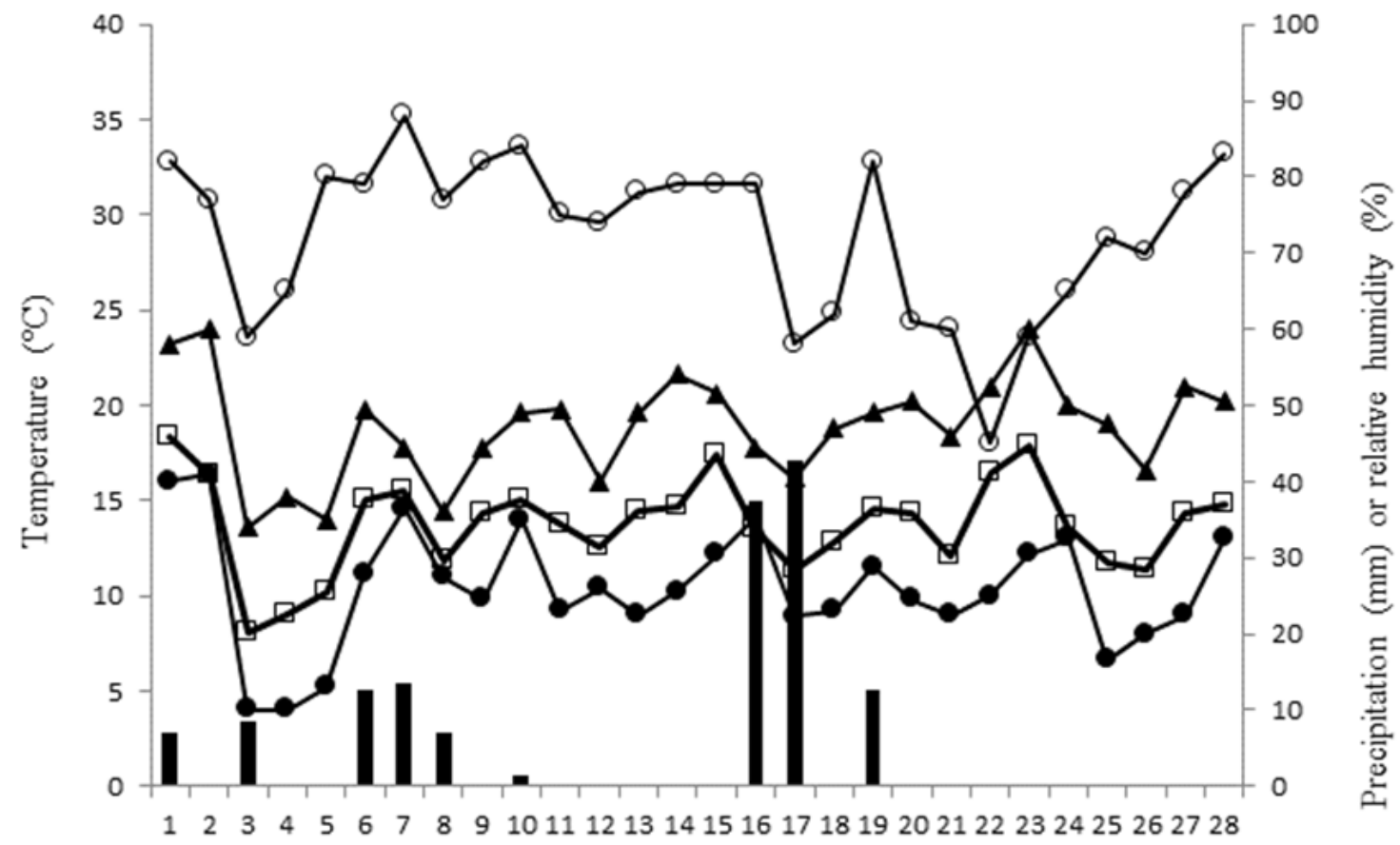

Days after inoculation (DAI)

Figure 1. Temperature, precipitation, and relative humidity observed during the period between the Phytophthora infestans inoculation to the last evaluation of disease severity in field experiments. Maximum ( $\boldsymbol{\Delta}$ ), medium ( $\square$ ), and minimum temperatures $(\bullet)$. Average relative humidity $(\circ)$, pluviometric precipitation (

From the SEV data, the area under the disease progress curve (AUDPC) for each potato genotype was calculated using the GW-BASIC program (MAFFIA, 1986). Tubers of each plot were harvested 108 days after planting, and the production was evaluated by weighing and determining the mass of the tubers of each plot ( $\mathrm{g}$ plot $\left.^{-1}\right)$.

The SEV data of the in vitro assay and the 
SEV, AUDPC, and tuber yield of the field experiment were submitted to analysis of variance (ANOVA). Means were compared using the ScottKnott grouping test at 5\% error probability, using the statistical software GENES (CRUZ, 2013). Based on AUDPC analysis and SEV values (28 DAI) for field trials, potato genotypes were grouped in different resistance levels: highly resistant; resistant; moderately resistant; moderately susceptible; susceptible; highly susceptible, according to the classification proposed by Gomes et al. (2009), including the positive (Bintje and Ágata susceptible) and negative (CIP392.617-54 resistant) controls. In addition, Pearson's (r) correlation analysis was performed between the AUDPC values and tuber yield, and between AUDPC and SEV of the in vitro experiment for the different genotype $\times$ oomycete isolate interactions, using the statistical software SAS version 9.0; SAS Institute, Inc., Cary, NC, USA (SAS, 2002).

\section{RESULTS AND DISCUSSION}

In the in vitro test, there was a significant $(p<$ 0.05 ) interaction between potato genotypes and $P$. infestans isolates. Potato genotypes inoculated with the A2 isolate formed distinct groups for late blight severity (Table 1). The highest percentages of severity (87.7-99.0\%) were observed for the cultivars Macaca, Bel, Clara, and Ana, and clones F63-01-06, C2557-2-06, CL02-05, F189-09-06, and RM98-23-05, which clustered together as a group along with the susceptible control Bintje. A second group was composed by cultivars Eliza and Asterix, clones CL20-01-06 and F23-24-06, and the susceptible control Ágata, which presented 64.2$81.2 \%$ of the diseased leaflet area. A third group showed relatively lower severity percentages $(27.0-$ $48.5 \%$ ), and was composed by clones C2573-4-06, C2569-1-06, C2551-2-06, C2553-1-06, C2545-1-06, and $\mathrm{C} 2550-4-06$, and. The clone $\mathrm{C} 2572-3-06$ had the lowest percentage of diseased leaflet area and was grouped with the resistant control CIP392.617-54.

Table 1. In vitro severity (\%) of two Phytophthora infestans isolates on detached leaflets of 23 potato genotypes.

\begin{tabular}{lcc}
\hline & & Isolate \\
\cline { 2 - 3 } Genotype & A2 Mating type & A1 Mating type \\
\hline Bintje & & $29.50 \mathrm{Ba}$ \\
Macaca & $99.00 \mathrm{Aa}^{3}$ & $17.50 \mathrm{Ba}$ \\
F63-01-06 & $98.50 \mathrm{Aa}$ & $18.00 \mathrm{Ba}$ \\
C2557-2-06 & $98.00 \mathrm{Aa}$ & $9.75 \mathrm{Bb}$ \\
CL02-05 & $97.75 \mathrm{Aa}$ & $24.25 \mathrm{Ba}$ \\
F189-09-06 & $96.50 \mathrm{Aa}$ & $39.00 \mathrm{Ba}$ \\
RM98-23-05 & $93.25 \mathrm{Aa}$ & $29.00 \mathrm{Ba}$ \\
Bel & $92.00 \mathrm{Aa}$ & $22.00 \mathrm{Ba}$ \\
Clara & $90.75 \mathrm{Aa}$ & $19.50 \mathrm{Ba}$ \\
Ana & $90.25 \mathrm{Aa}$ & $25.25 \mathrm{Ba}$ \\
Asterix & $87.75 \mathrm{Aa}$ & $33.75 \mathrm{Ba}$ \\
Eliza & $81.25 \mathrm{Ab}$ & $0.10 \mathrm{Bb}$ \\
F23-24-06 & $76.25 \mathrm{Ab}$ & $39.50 \mathrm{Ba}$ \\
CL20-01-06 & $74.00 \mathrm{Ab}$ & $22.00 \mathrm{Ba}$ \\
Ágata & $75.00 \mathrm{Ab}$ & $25.75 \mathrm{Ba}$ \\
C2550-4-06 & $64.25 \mathrm{Ab}$ & $3.75 \mathrm{Bb}$ \\
C2545-1-06 & $48.50 \mathrm{Ac}$ & $12.00 \mathrm{Ab}$ \\
C2553-1-06 & $30.00 \mathrm{Ac}$ & $4.52 \mathrm{Bb}$ \\
C2551-2-06 & $41.25 \mathrm{Ac}$ & $0.55 \mathrm{Bb}$ \\
C2569-1-06 & $39.25 \mathrm{Ac}$ & $21.50 \mathrm{Aa}$ \\
C2573-4-06 & $35.50 \mathrm{Ac}$ & $0.00 \mathrm{Bb}$ \\
C2572-3-06 & $27.02 \mathrm{Ac}$ & $6.27 \mathrm{Ab}$ \\
CIP392.617-54 & $15.00 \mathrm{Ad}$ & $0.00 \mathrm{Ab}$ \\
\hline CV (\%) & $1.75 \mathrm{Ad}$ & 42.76 \\
\hline & 22.75 & \\
\hline & & \\
\hline
\end{tabular}

${ }^{1}$ Susceptible control; ${ }^{2}$ resistant control; ${ }^{3}$ means followed by the same uppercase letters on the line and lowercase letters in the column belong to the same group according to the Scott-Knott test at $5 \%$ probability. 
When inoculated with the A1 isolate, lower percentages of late blight severity of potato genotypes were observed when compared with the A2 isolate experiment, as evidenced by the injured leaf area, which varied from $0.0 \%$ (CIP392.617-54) to $39.5 \%$ (clone F23-24-06) (Table 1). By comparing the mean values, the genotypes were grouped into only two groups. The group with the lowest percentages of SEV was composed by C2545-1-06, C2557-2-06, C2572-3-06, C2553-1-06, C2550-4-06, C2551-2-06, C2573-4-06, Eliza, and the resistant control CIP392.617-54. The other genotypes, with SEV of $17.5-39.5 \%$, were grouped with the susceptible controls, Ágata and Bintje (Table 1).

According to the results obtained in the field trials for the AUDPC and SEV variables (Table 2), there was a significant interaction between potato genotypes and $P$. infestans isolates. Regarding the reaction of potato genotypes to the $\mathrm{A} 2$ isolate, cultivars Bel, Macaca, Asterix, Clara, and Ana, and clones F189-09-06, RM9823-05, CL02-05, F23-2406, F63-01-06, CL20-01-06, and C2545-1-06 were deemed highly susceptible (1320.26> AUDPC $<1634.00$; SEV $=100.0 \%$ ), as they grouped with the susceptible controls, Ágata and Bintje. The clone C2572-3-06 and cultivar Eliza reacted as susceptible $(643.60>$ AUDPC $<822.93 ; 74.0 \%>$ SEV $<81.7 \%$ ); C2569-1-06 and C2557-2-06, moderately susceptible $(396.33>$ AUDPC $<465.66 ; 33.0 \%>$ $\mathrm{SEV}<56.7 \%$ ); and $\mathrm{C} 2573-4-06$ and $\mathrm{C} 2553-1-06$, moderately resistant $(283.00>$ AUDPC $<333.33$; $33.0 \%>\mathrm{SEV}<44.3 \%$ ). The clone $\mathrm{C} 2550-4-06$ was resistant $(\mathrm{AUDPC}=175.56 ; \mathrm{SEV}=21.3 \%)$; and C2551-2-06, highly resistant (AUDPC $=7.33$; SEV $=1.0 \%$ ) compared with the resistant control CIP392.617-54.

Table 2. Mean values of the area under the disease progress curve (AUDPC), disease severity (SEV), and late blight resistance reaction of 23 potato genotypes inoculated with two Phytophthora infestans isolates in field conditions.

\begin{tabular}{|c|c|c|c|c|c|c|}
\hline \multirow[b]{2}{*}{ Genotype } & \multicolumn{3}{|c|}{ A2 Mating type } & \multicolumn{3}{|c|}{ A1 Mating type } \\
\hline & AUDPC & $\begin{array}{c}\text { Severity } \\
(\%)\end{array}$ & Reaction $^{1}$ & AUDPC & $\begin{array}{c}\text { Severity } \\
(\%)\end{array}$ & Reaction \\
\hline F189-09-06 & $1634.00 \mathrm{Aa}^{4}$ & $100.0 \mathrm{Aa}$ & $\mathrm{HS}$ & $155.26 \mathrm{Bd}$ & $31.66 \mathrm{Bb}$ & $\mathrm{R}$ \\
\hline Ágata $^{2}$ & $1610.33 \mathrm{Aa}$ & $100.0 \mathrm{Aa}$ & HS & $520.00 \mathrm{Ba}$ & $80.33 \mathrm{Aa}$ & S \\
\hline RM98-23-05 & $1609.33 \mathrm{Aa}$ & $100.0 \mathrm{Aa}$ & HS & $422.16 \mathrm{Bb}$ & $64.00 \mathrm{Ba}$ & MS \\
\hline Bel & $1583.50 \mathrm{Aa}$ & $100.0 \mathrm{Aa}$ & HS & $424.43 \mathrm{Bb}$ & $54.70 \mathrm{Bb}$ & MS \\
\hline Macaca & $1579.50 \mathrm{Aa}$ & $100.0 \mathrm{Aa}$ & HS & $492.26 \mathrm{Ba}$ & $72.70 \mathrm{Ba}$ & S \\
\hline CL02-05 & $1578.16 \mathrm{Aa}$ & $100.0 \mathrm{Aa}$ & HS & $224.50 \mathrm{Bc}$ & $45.33 \mathrm{Bb}$ & MR \\
\hline F23-24-06 & $1569.83 \mathrm{Aa}$ & $100.0 \mathrm{Aa}$ & HS & $279.33 \mathrm{Bc}$ & $46.66 \mathrm{Bb}$ & MR \\
\hline Asterix & $1569.50 \mathrm{Aa}$ & $100.0 \mathrm{Aa}$ & HS & $419.00 \mathrm{Bb}$ & $70.00 \mathrm{Ba}$ & MS \\
\hline Clara & $1547.50 \mathrm{Aa}$ & $100.0 \mathrm{Aa}$ & HS & $366.26 \mathrm{Bb}$ & $47.33 \mathrm{Bb}$ & MS \\
\hline Ana & $1526.00 \mathrm{Aa}$ & $100.0 \mathrm{Aa}$ & HS & $358.60 \mathrm{Bb}$ & $47.00 \mathrm{Bb}$ & MS \\
\hline Bintje $^{2}$ & $1501.16 \mathrm{Aa}$ & $100.0 \mathrm{Aa}$ & HS & $385.56 \mathrm{Bb}$ & $64.00 \mathrm{Ba}$ & MS \\
\hline F63-01-06 & $1486.16 \mathrm{Aa}$ & $100.0 \mathrm{Aa}$ & HS & $164.26 \mathrm{Bd}$ & $17.00 \mathrm{Bc}$ & R \\
\hline CL20-01-06 & $1427.16 \mathrm{Ab}$ & $100.0 \mathrm{Aa}$ & HS & $71.00 \mathrm{Be}$ & $9.33 \mathrm{Bc}$ & HR \\
\hline C2545-1-06 & $1320.26 \mathrm{Ac}$ & $100.0 \mathrm{Aa}$ & HS & $40.66 \mathrm{Be}$ & $9.00 \mathrm{Bc}$ & HR \\
\hline Eliza & $822.93 \mathrm{Ad}$ & $81.7 \mathrm{Ab}$ & $\mathrm{S}$ & $30.23 \mathrm{Be}$ & $3.66 \mathrm{Bd}$ & HR \\
\hline C2572-3-06 & $643.60 \mathrm{Ae}$ & $74.0 \mathrm{Ac}$ & S & $4.66 \mathrm{Be}$ & $1.00 \mathrm{Bd}$ & HR \\
\hline C2569-1-06 & $396.33 \mathrm{Af}$ & 56.7Ac & MS & $0.67 \mathrm{Be}$ & $0.33 \mathrm{Bd}$ & HR \\
\hline C2557-2-06 & $465.66 \mathrm{Af}$ & $33.0 \mathrm{Ae}$ & MS & $4.66 \mathrm{Be}$ & $1.00 \mathrm{Bd}$ & HR \\
\hline C2553-1-06 & $333.33 \mathrm{Ag}$ & $44.3 \mathrm{Ad}$ & MR & $0.67 \mathrm{Be}$ & $0.33 \mathrm{Bd}$ & HR \\
\hline C2573-4-06 & $283.00 \mathrm{Ag}$ & $33.0 \mathrm{Ae}$ & MR & $2.00 \mathrm{Be}$ & $1.00 \mathrm{Bd}$ & HR \\
\hline C2550-4-06 & $175.56 \mathrm{Ah}$ & $21.3 \mathrm{Af}$ & $\mathrm{R}$ & $2.00 \mathrm{Be}$ & $0.33 \mathrm{Bd}$ & HR \\
\hline C2551-2-06 & $7.33 \mathrm{Ai}$ & $1.0 \mathrm{Ag}$ & HR & $0.00 \mathrm{Ae}$ & $0.00 \mathrm{Ad}$ & HR \\
\hline CIP392.617-54 & $0.00 \mathrm{Ai}$ & $0.0 \mathrm{Ag}$ & HR & $0.00 \mathrm{Ae}$ & $0.00 \mathrm{Ad}$ & HR \\
\hline CV (\%) & 6.31 & 7.52 & & 30.21 & 25.40 & \\
\hline
\end{tabular}

${ }^{1}$ Reaction: HS = highly susceptible; $\mathrm{S}=$ susceptible; $\mathrm{MS}=$ moderately susceptible; $\mathrm{MR}=$ moderately resistant; $\mathrm{R}=$ resistant; HR = highly resistant; ${ }^{2}$ susceptible control; ${ }^{3}$ resistant control; ${ }^{4}$ Means followed by the same uppercase letters on the line and lowercase letters in the column belong to same group, according to the Scott-Knott test at $5 \%$ probability.

For the same set of genotypes inoculated with the A1 isolate, in general, lower values of AUDPC and percentages of SEV were observed (Table 2). Thus, the cultivar Macaca was grouped with the susceptible control Ágata (492.26 > AUDPC < 520; $72.7 \%>$ SEV $<80.3 \%$ ). The clone RM98-23-05 and cultivars Bel, Asterix, Clara, Ana, and Bintje formed a second group categorized as moderately susceptible $(358.60>$ AUDPC $<424.43 ; 47.0 \%>$ SEV < 54.7\%); CL02-05 and F23-24-06, moderately resistant $(224.50>$ AUDPC $<279.33 ; 45.3 \%>$ SEV $<$ 46.7\%); F189-09-06 and F63-01-06, resistant $(155.26>$ AUDPC < 164.26; 17.0\% > SEV $<31.7 \%$ ); Eliza, CL20-01-06, and the nine clones improved for resistance to $P$. infestans (C2572-3-06, C2557-2-06, C2569-1-06, C2553-1-06, C2573-4-06, 
C2550-4-06, C2551-2-06, C2545-1-06, and the resistant control CIP392.617-54) reacted as highly resistant $(0.00>$ AUDPC $<71.00 ; 0.0 \%>$ SEV $<$ $9.3 \%)$.

Similar to the in vitro experiment, the A2 isolate was more aggressive than the A1 isolate, in the field experiments (Table 2). Severity percentages were $100.0 \%$ at $28 \mathrm{DAI}$ in 14 of the 23 genotypes, and this isolate was more aggressive than the A1 isolate in 21 of the 23 genotypes. There was no influence of the isolate type on the severity of $P$. infestans, except for Ágata cultivar (positive control) and the two highly resistant clones (CIP392.617-54 and C2551-2-06). Despite small differences, the resistance reaction was characterized by the grouping of the AUDPC variable as a function of the disease accumulation over time.

When comparing the SEV percentages observed in the in vitro test with the AUDPC values of the field experiment inoculated with A2 isolate, a strong positive correlation was calculated $(r=0.74, p$ $<$ 0.0001). Likewise, in the field experiment inoculated with the less aggressive isolate A1, there was also a positive correlation between the in vitro and in vivo evaluations $(r=0.68, p<0.0004)$ (Tables 1 and 2).

The ANOVA of tuber yield showed significant differences in the interaction between potato genotypes and $P$. infestans isolates (Table 3 ). In 19 out of the 23 genotypes inoculated with A2 isolate, a lower average tuber weight was recorded when compared with those inoculated with A1 isolate, corresponding, in general, to the highest AUDPC values. Thus, a strong negative correlation $(r=-0.83, p<0.0001)$ existed between the two variables. Similarly, for the less aggressive isolate (A1), a moderate negative correlation $(r=-0.40, p<$ 0.0001 ) was noted between AUDPC and tuber yield.

Table 3. Means of tuber yield reduction for genotypes inoculated with A2 isolate compared with those inoculated with A1 isolate of 23 potato genotypes inoculated with the two isolates of Phytophthora infestans in field experiments.

\begin{tabular}{|c|c|c|c|}
\hline \multirow{2}{*}{ Genotype } & \multicolumn{2}{|c|}{ Tuber yield $\left(\mathrm{g} \mathrm{plot}^{1}\right)$} & \multirow{2}{*}{$\begin{array}{c}\text { Tuber yield } \\
\text { reducction (\%) }\end{array}$} \\
\hline & A2 Mating type & A1 Mating type & \\
\hline CIP392.617-54 & $2668 \mathrm{Aa}^{3}$ & $2804 \mathrm{Ac}$ & $4.85^{\mathrm{ns}}$ \\
\hline C2573-4-06 & $2304 \mathrm{Ba}$ & $3250 \mathrm{Ab}$ & $29.10^{*}$ \\
\hline C2569-1-06 & $2148 \mathrm{Aa}$ & $2553 \mathrm{Ac}$ & $15.86^{\mathrm{ns}}$ \\
\hline C2553-1-06 & $1581 \mathrm{Bb}$ & $3254 \mathrm{Ab}$ & $51.41 *$ \\
\hline C2551-2-06 & $1532 \mathrm{Ab}$ & $1778 \mathrm{Ad}$ & $13.85^{\text {ns }}$ \\
\hline C2572-3-06 & $1502 \mathrm{Bb}$ & $2772 \mathrm{Ac}$ & $45.81^{*}$ \\
\hline C2550-4-06 & $1460 \mathrm{Bb}$ & $3792 \mathrm{Aa}$ & $65.50 *$ \\
\hline C2557-2-06 & $1309 \mathrm{Bb}$ & $4012 \mathrm{Aa}$ & $32.62 *$ \\
\hline Eliza & $1050 \mathrm{Bc}^{+}$ & $2386 \mathrm{Ac}$ & $54.00^{*}$ \\
\hline Clara & $1048 \mathrm{Bc}^{+}$ & $1935 \mathrm{Ad}^{+}$ & $45.83^{*}$ \\
\hline Bel & $1032 \mathrm{Bc}$ & 2549 Ac & $59.51 *$ \\
\hline Ana & $877 \mathrm{Bc}$ & $2379 \mathrm{Ac}$ & $63.13 *$ \\
\hline F63-01-06 & $811 \mathrm{Bc}$ & $2815 \mathrm{Ac}^{+}$ & $71.13^{*}$ \\
\hline C2545-1-06 & $681 \mathrm{Bc}$ & $1882 \mathrm{Ad}$ & $63.81^{*}$ \\
\hline Ágata $^{1}$ & $653 \mathrm{Bc}$ & $1501 \mathrm{Ad}$ & $56.49^{*}$ \\
\hline CL20-01-06 & $648 \mathrm{Ac}$ & $922 \mathrm{Ae}$ & $29.71^{\mathrm{ns}}$ \\
\hline F23-24-06 & $598 \mathrm{Bc}$ & $1709 \mathrm{Ad}^{+}$ & $65.00^{*}$ \\
\hline Bintje $^{1}$ & $536 \mathrm{Bc}$ & $1590 \mathrm{Ad}^{+}$ & $66.28^{*}$ \\
\hline Asterix & $508 \mathrm{Bc}^{+}$ & 1496 Ad & $66.04 *$ \\
\hline Macaca & $426 \mathrm{Bc}$ & $1059 \mathrm{Ae}$ & $59.77 *$ \\
\hline CL02-05 & $303 \mathrm{Bc}$ & $2338 \mathrm{Ac}$ & $87.41^{*}$ \\
\hline F189-09-06 & $253 \mathrm{Bc}^{+}$ & $1040 \mathrm{Ae}$ & $75.67 *$ \\
\hline RM98-23-05 & $149 \mathrm{Bc}$ & $1687 \mathrm{Ad}$ & $91.16^{*}$ \\
\hline CV (\%) & 23.03 & 21.31 & \\
\hline
\end{tabular}

${ }^{1}$ susceptible control; ${ }^{2}$ resistant control; ${ }^{3}$ means followed by the same uppercase letters on the line and lowercase letters in the column belong to the same group, according to the Scott-Knott test at $5 \%$ probability; ${ }^{+}$tuber infected with $P$. infestans; $*(p<0.05)$; ns $=$ not significant. 
Included in the four genotypes that showed no significant differences in tuber yield for both isolates, C2551-2-06 and the resistant control CIP392.617-54 were highly resistant, C2569-1-01 was moderately susceptible/highly resistant, and CL20-01-06 was highly susceptible/highly resistant to A2 and A1 isolates, respectively (Table 3). Potato genotypes that showed higher levels of resistance generally had higher tuber yields than susceptible genotypes. These differences were also related to the aggressiveness of field-tested $P$. infestans isolates.

In this study, the potato clones C2551-2-06, C2550-4-06, C2573-4-06, and C2553-1-06 were classified as highly resistant to two isolates of $P$. infestans from the two mating types and different races, in both the field and in vitro experiments. These clones were obtained by selection of the population generated from crosses between potato genitors used in the Embrapa breeding program and clones of the B3 population selected by the CIP for late blight horizontal resistance (LANDEO et al., 2001), as previously confirmed (MULEMA et al., 2004; WULFF et al., 2007), and which, are known to present high yields of tubers (NAMUGGA et al., 2018). The reaction of the cultivars Ágata, Asterix, Bintje, and Ana, confirmed their susceptibility, as reported by other authors (GOMES et al., 2009; DUARTE et al., 2012). In the specific case of cultivar Eliza, the instability of the reaction to the more aggressive isolate demonstrates the apparent presence of major $R$ genes in this clone.

The differences in aggressiveness of the $P$. infestans isolates verified in this study confirm observations of great variability in aggressiveness of the pathogen isolates reported by Cooke et al. (2012). These authors found genotype 13-A2 to be more aggressive than older genotypes, becoming dominant in a short time in north-western Europe. Pathogenic variation within clonal lineages was probably due to mutation, selection, and genetic drift (GOODWIN et al., 1995). In Brazil, in the last few years, these changes have mainly occurred because of more than one clonal lineage, gene flow, and appearance of new genotypes, indicating variability in their genetic and phenotypic traits, and implying the occurrence of isolates with simple and complex virulence genes (SANTANA et al., 2013; CASA, 2014; CASA-COILA et al., 2017). These assumptions are confirmed by our results, in which the A2 isolate, with ten virulence genes, was more aggressive than the A1 isolate with two virulence genes. Consequently, the occurrence of aggressive $P$. infestans pathotypes may predispose the potato to severe epidemics of late blight.

The detached leaflet method was moderately correlated with the field test, for disease severity. According to Sharma et al. (2013), a moderate correlation of resistance of potato genotypes to $P$. infestans was also found between the detached leaflet and field trial assays. However, in this study, genotypes with high resistance in the field were identified as having a lower level of resistance in the leaflet test when it was inoculated with the more aggressive isolate, suggesting caution in the results of the detached leaflet test. The correlation of in vitro evaluation methods with field tests to evaluate the resistance levels of $P$. infestans in potato cultivars has shown marked differences in resistance stability between the tested genotypes (MICHALSKA et al., 2011).

The results of in vitro tests can constitute an auxiliary measure in pre-selection of potato clones for $P$. infestans resistance. According to Sharma et al. (2013), the use of these methods to determine the resistance of potato genotypes to $P$. infestans is an alternative in evaluating the phenotypic reaction of potatoes, especially for susceptible materials. However, based on the results obtained in this study, it is necessary to carry out field tests to confirm the reaction of the genotypes observed in the in vitro test. The in vitro assays can be useful only when there is a vast number of clones to be evaluated. This method would shorten the selection process, despite the risk of losing some promising genotypes.

The variability of $P$. infestans in Brazil (REIS et al., 2003; SANTANA et al., 2013; CASA-COILA et al., 2017) is reflected in the differences in aggressiveness among the isolates evaluated in this study. Thus, the use of potato genotypes with durable resistance to several $P$. infestans pathotypes as a strategy for late blight control, along with other agronomic practices, will reduce yield losses and decrease production costs, by lowering the dependence on fungicide sprays. In this sense, potato clones that presented higher levels of resistance to $P$. infestans isolates of different races, but not yet display all necessary characteristics to become a cultivar, are suitable materials to be used as parental lines in crosses to generate populations aiming to develop cultivars with resistance to late blight.

\section{CONCLUSION}

There is variability in the genetic resistance of potato genotypes to $P$. infestans under field conditions, as well as interactions between the pathogen isolates and potato clones tested. Under the conditions used in these experiments, a positive correlation exists between field trials and in vitro assays that evaluate potato genotypes for resistance to $P$. infestans. The A2 mating type isolate was more aggressive than the A1 mating type, for the majority of the examined potato genotypes.

\section{ACKNOWLEDGMENTS}

To the Student Post-Graduate Agreement Program (PEC-PG) of the Coordination of 
Improvement of Higher Education Personnel (PEC-PG/CAPES), for providing Victor a scholarship. To the Federal University of Pelotas, Graduate Program in Plant Protection; and to Embrapa Temperate Climate, for providing the infrastructure and support for the development of this work. Ailton Reis thanks $\mathrm{CNPq}$ for providing him with a research productivity scholarship. Thanks to Fernando Tavares (In Memoriam), Gelson, Dediel Rocha, Daniele de Brum, and Fernanda Cruz for their valuable contributions toward the field work.

\section{REFERENCES}

BLACK, W. et al. A proposal for an international nomenclature of races of Phytophthora infestans and of genes controlling immunity in Solanum demissum derivatives. Euphytica, v. 2, n. 3, p. 173-178, 1953.

BYARUGABA, A. A.; PROSSY, N.; KASHAIJA, I. $\mathrm{N}$. Identification of potato clones of population B3C2 with durable field resistance to late blight (Phytophthora infestans) and high yields in Uganda. African Journal of Agricultural Research, v. 8, n. 23 , p. $3055-3059,2013$.

CASA, V. H. C. Caracterização de isolados de Phytophthora infestans (Mont.) De Bary provenientes de batata do Sul do Brasil associada ao estudo da resistência em Solanum spp. 2014. 126 f. Tese (Doutorado em Fitossanidade: Área de Concentração em Fitopatologia) - Universidade Federal de Pelotas, Pelotas, 2014.

CASA-COILA, V. H. et al. First report of Phytophthora infestans self-fertile genotypes in southern Brazil. Plant Disease, v. 101, n. 9, p. 1682 , 2017.

CLIVE, J. W. An illustrated series of assessment keys for plant diseases their preparation and usage. Edit. W.L. Seaman. Canadian Plant Disease Survey, v. 51, n. 2, p. 39-65, 1971.

COLON, L.; NIELSON, B. J.; DARSON, U. Euroblight protocol: Detached leaf test for foliage blight resistance. 1. ed. Lelystad, UE: EUROBLIGHT, 2004. 3 p.

COOKE, D. E. L. et al. Genome analyses of an aggressive and invasive lineage of the Irish potato famine pathogen. PLoS Pathogens, v. 8, n. 10, p. 1$14,2012$.

CRUZ, C. D. GENES: a software package for analysis in experimental statistics and quantitative genetics. Acta Scientiarum, v. 35, n. 3, p. 271-276, 2013.
DUARTE, H. S. S. et al. The field resistance of potato cultivars to foliar late blight and its relationship with foliage maturity type and skin type in Brazil. Australasian Plant Pathology, v. 41, n. 2, p. 139-155, 2012.

FOOD AND AGRICULTURE ORGANIZATION OF THE UNITED NATIONS - FAO. FAOSTAT database. In: Food and agriculture organization of the United Nations (Ed.). Food and Agriculture Organization of the United Nations. Italy: Rome. (Available at: http://faostat.fao.org/), 2018.

FRY, W. et al. Historical and recent migrations of Phytophthora infestans: chronology, pathway, and implications. Plant Disease, v. 77, n. 7, p. 653-661, 1993.

FRY, W. Phytophthora infestans: The plant (and R gene) destroyer. Molecular Plant Pathology, v. 9, n. 3, p. 385-402, 2008.

GISI, U. et al. Changes of genotype, sensitivity and aggressiveness in Phytophthora infestans isolates collected in European countries in 1997, 2006 and 2007. Journal of Phytopathology, v. 159, n. 4 p. 223-232, 2011.

GOMES, C. B. et al. Reação de genótipos de batata a requeima (Phytophthora infestans). 1. ed. Pelotas, RS: EMBRAPA, 2009. 17 p. (Boletim de Pesquisa e Desenvolvimento, 83).

GOODWIN, S. B. et al. Rapid evolution of pathogenicity within clonal lineages of the potato late blight disease fungus. Phytopathology, v. 85, n. 6, p. $669-676,1995$.

LANDEO, J. A. et al. Quantifying genetic variance for horizontal resistance to late blight in potato breeding population B3C1. In: Scientist and FarmerPartners in Research for the 21st Century, 2001, Lima. CIP Program report 1999-2000. Lima: International Potato Center, 2001. p. 63-68.

MAFFIA, A. L. Programa para cálculo de área abaixo da curva do progresso da doença (AACPD) GW-BASIC 3.20. Viçosa, MG: Universidade Federal de Viçosa, 1986.

MICHALSKA, A. M. et al. Resistance of potato to stem infection by Phytophthora infestans and a comparison to detached leaflet and field resistance assessments. American Journal of Potato Research, v. 88, n. 4, p. 367-373, 2011.

MULEMA, J. M. K. et al. Stability of late blight resistance in population $\mathrm{B}$ potato clones. Potato Research, v. 47, n. 1-2, p. 11-24, 2004. 
NAKITANDWE, J. et al. Resistance to late blight and yield of population B3 potato selection in Uganda. African Crop Science Journal, v. 13, n. 2, p. $95-105,2005$.

NAMUGGA, P. et al. Yield Response of Potato (Solanum tuberosum L.) Genotypes to late blight caused by Phytophthora infestans in Uganda. American Journal of Potato Research, v. 95, n. 4, p. 423-434, 2018.

NAZARENO, N. R. X. et al. Controle da requeima da batata através do monitoramento das variáveis climáticas. Fitopatologia Brasileira, v. 24, n. 2, p. 170-174, 1999.

NDACYAYISENGA, T. et al. Yield stability and late blight resistance analysis among potato clones bred with quantitative resistance. Journal of Agricultural Science and Technology, v. 4, n. 4, p. $683-690,2014$.

ORONA, C. A. L. et al. First report of homothallic isolates of Phytophthora infestans in commercial potato crops (Solanum tuberosum) in the Toluca Valley, Mexico. Plant Disease, v. 97, n. 8, p. 1112, 2013.

PEREIRA, A. S. et al. Melhoramento para resistência a oomicetos. In: FRITSCHE-NETO, R.; BORÉM, A. (Eds.). Melhoramento de plantas para condições de estresses bióticos. Viçosa: UFV, 2012. v. 1 , cap. 2 , p. 25-59.

REIS, A. et al. Characterization of isolates of Phytophthora infestans from Southern and Southeastern Brazil from 1998 to 2000. Plant Disease, v. 87, n. 8, p. 896-900, 2003.

SANTANA, F. M. et al. Characterization of Phytophthora infestans populations of southern Brazil in 2004 and 2005. Phytoparasitica, v. 41, n. 5 , p. $557-568,2013$.

STATISTICAL ANALYSIS SYSTEM USER'S GUIDE. - SAS INSTITUTE. Version 9.0. Cary: SAS Institute. 2002.

SHARMA, B. P. et al. Determination of resistance to Phytophthora infestans on potato plants in field, laboratory and greenhouse conditions. Journal of Agricultural Science, v. 5, n. 5, p. 148-157, 2013.

VAN DER PLANK, J. E. Stability of resistance to Phytophthora infestans in cultivars without $\mathrm{R}$ genes. Potato Research, v. 14, n. 4, p. 263-270, 1971.

WULFF, E. G. et al. Identification of stable resistance to Phytophthora infestans in potato genotypes evaluated in field experiments in Peru. Experimental Agriculture, v. 43, n. 3, p. 353-363, 2007.

ZAMBOLIM, L.; DUARTE, H. S. S.; ZAMBOLIM, E. M. Medidas integradas de controle das doenças fúngicas da batata. In: ZAMBOLIM, L. (Ed.). Produção integrada da batata. Viçosa, MG: UFV, 2011. v. 1, cap. 11, p. 411-438. 